with scholars from the respective countries. Sam began these projects because of his intellectual curiosity, his desire to learn and study political parties in a broad context, and an innate commitment to teach and collaborate with other scholars.

In addition to the Woodrow Wilson Award, Sam received much professional recognition for his scholarship. He was elected to the American Academy of Arts and Sciences in 1977. In 1987, the Political Organizations and Parties section of the APSA created the Eldersveld Lifetime Contribution award and immediately presented it to Sam. Closer to home, the University of Michigan recognized Sam as the Senior Distinguished Professor lecturer for 1986 and the department's conference room was named the Eldersveld Room.

Sam's approach to academic organizations was just as farsighted as his approach to his scholarship. He became chair of the Michigan political science department in 1964, with the goal of making it one of the country's best departments. He was determined that the department would hire the "brightest and best," regardless of any defined positions or slots. During the period of his chairship, the department hired 30 new faculty members, while losing 17 to retirement, death, or moves to other universities. It was both the absolute growth and the replacements that made the department a top department.

He also believed that the behavioral approach he adopted for his own work was the future for the department. When recruiting one of those 30 new members, who later became a very prominent scholar at Michigan, one of Sam's older colleagues remarked that what this person did was not political science. To which Sam responded, "This may not be the way we were taught to do political science, but it is the way political science will be done in the future." Just as his own work moved away from his traditional training, so the department moved away from its traditional roots. Sam was not dogmatic in pursuing this view, but the department certainly acquired a behavioral orientation and reputation during his tenure.

Sam showed the same vision and skill used to transform the political science department in significantly altering the teaching and research used to train public officials. When he became department chair, most of the appointments and work in the Institute of Public Administration were located in political science. Sam saw that an interdisciplinary approach using many of the behavioral and analytical concepts that he had pushed the department to adopt needed to be the basis for a new public policy curriculum. As department chair, Sam was in a position to encourage the public administration faculty to adapt or look for new positions. He was appointed to chair a committee to define the future for the Institute and its educational and scholarly mission. The result was the creation of the Institute of Public Policy Studies, built on a multidisciplinary faculty drawn from a number of departments and other units. The Institute became a leader in the emerging field of public policy and ultimately became the Gerald R. Ford School of Public Policy.

Sam did not just study political leaders, he was one. In the mid-1950s, he applied what he had learned about party organizations and voter turnout to become Ann Arbor's first Democratic mayor since 1931. His research had shown that personal contact was the most effective way to get people to the polls. To implement that finding, his campaign created organizations in each precinct whose task was to contact those likely to vote Democratic. Then, a well-organized phone bank contacted these people again on Election Day. This organizational work was backed by continuing survey work under the direction of Morris Janowitz. With this political machine behind him, Sam collected $53 \%$ of the vote to become mayor in April 1957.

The election was followed by a steady stream of confrontations with the Republican-dominated City Council. In most of these confrontations, Sam routinely showed his Dutch tenacity and frequently prevailed. On of his proudest accomplishments was the passage of a human rights ordinance and the creation of the state's first Human Relations Commission to investigate and report on allegations of discrimination. This commission, renamed the Human Rights Commission, still exists.

Sam was a formidable and courageous administrator, both academically and governmentally. Organizations large and small, private and public, reach a point of needing bold reforms, and some leaders have clear visions of the future, but both languish because of inability and lack of courage to act decisively. As evidenced in his positions as department chair, mayor, and advisor to the Institute of Public Administration and then the Institute of Public Policy Studies, Sam saw when rad- ical changes needed to be made and exercised the leadership to execute them, often in the face of strenuous resistance.

Sam's personal life had it various moments, but a highlight was when he met Els Nieuwenhuijsen at a meeting of the Netherlands American University League in October 1985. This meeting blossomed into a deep friendship, with Els traveling with Sam to China, among other places. They were married in 2000, and Els became much more than a partner for Sam. She helped with his last two projects after his eyesight and then his health began to fail. She was devoted to him and vice-versa. Her presence for the last 25 years of his life had a profound effect on Sam that was evident to all. Sam had two children, Lucy Angeline Murphy and Samuel Keith Eldersveld, and two grandchildren, Colin and Beth, that he adored and valued.

A constant in all his ventures was Sam's honesty, directness, and commitment to social justice. As an administrator, he emphasized transparency. One always knew where one stood with Sam. He had reasons for doing things, and he stated them openly and honestly. The policies and decisions he espoused were often opposed, but his candor always contributed positively to the health of the organization. His commitment to social justice at all levels of society is legendary, as evidenced by his pride in the Ann Arbor Human Rights Commission and his encouragement of Els's work with the Ann Arbor Disability Commission. Sam's passing is to be lamented, but his legacy and contributions evident in his students, family, scholarship and the institutions he led will be with us and treasured forever.

John E. Jackson
University of Michigan
M. Kent Jennings
University of California, Santa Barbara,
and University of Michigan
Lawrence B. Mohr
University of Michigan
Hanes Walton, Jr.
University of Michigan

\section{GIL FRIEDMAN}

Gil Friedman, lecturer in political science at Tel Aviv University, passed away on July 16, 2009, at the age of 42 after a short bout with cancer. Much too young, and with so much promise, Gil's death was an unexpected shock to his relatives, friends, 
and colleagues. His loss is all the more tragic because those who knew Gil were struck by his seemingly boundless energy, his enormous intellectual curiosity, his constant stream of ideas, and his incredible work ethic-all fed by a seemingly insatiable desire to read everything (ever) written in the areas of his current interest.

With an undergraduate degree in sociology from the University of Chicago, it is no surprise that Gil's main focus was on conflict processes across a variety of levels of analysis. Both his master's thesis from the University of New Mexico (1994) and his Ph.D. dissertation from the University of South Carolina (2002) focused on the relationships between internal and external conflict, and the two-level games played between governments and societies, or elites and the masses, in the complex Middle East conflict system. Gil's main research interests were conflict theory in general and protracted conflict in particular, with the Palestinian-Israeli conflict as an ongoing case for analysis. These areas, and others, were situated within an excellent grasp of philosophy of science, epistemology, and the logic of inquiry, along with international relations theory, especially realist theory.

In 1997, Gil and I co-authored a book dealing with international relations theory and the philosophy of science, Agency, Structure and International Politics: From Ontology to Empirical Inquiry (Routledge). In this work, we used the opportunity and willingness framework as a springboard to grapple with the broader debate in the literature concerning the agent-structure relationship. This was a truly collaborative project that developed from papers that Gil was writing for one of our directed readings courses. Both the agent-structure question and the opportunity and willingness framework were central to Gil's concern with two-level conflict. In the development of Agency, Structure and International Politics, Gil demonstrated a breadth of knowledge and a feel for the subtlety of political philosophy that would have been impressive for a senior scholar in this area. Gil demonstrated the same strengths in his written comprehensive exams and his orals (which his committee felt were completed with distinction), as well as his dissertation, Toward a Spatial Model of Protracted Conflict Management: The Palestinian Case.

His dissertation project on intraPalestinian conflict over the issue of strat- egy toward Israel stems from the same broad concerns. In it, Gil aimed to synthesize and develop his own model for the analysis of two-level conflict. He aimed for a model that could deal with the complexities of protracted conflict and the impact of external international factors on the internal political process of coalition building. Gil demonstrated flexibility and nimbleness of intellect when he had to redesign his research after getting into the field, using multiple datasets and sources including the use of Palestinian public opinion data. His dissertation was the basis for his 2005 Journal of Conflict Resolution article, "Commercial Pacifism and Protracted Conflict: Models from the Palestinian Case," as well as three pieces that were under review at the time of his death, "Dual-Track Strategy in Ethno-nationalist Peacemaking: Models from the Palestinian Case," "A General Framework for the Analysis of Third-Party Effects on International and Domestic Conflict: The Case of Syria," and "Toward a Spatial Model of the Domestic Politics of Protracted Ethnonationalist Conflict Resolution." His article, "Coser on Rallying and Diversion," accepted for publication at the Review of International Studies, also stemmed from his interest in the relationship between elites and followers. In addition, Gil published articles in the International Studies Review and the Journal of Strategic Studies, and several book chapters. His chapter, "Rational Counterterrorism Strategy in Asymmetric Protracted Conflicts and Its Discontents: The Israeli-Palestinian Case," will be published in 2010 in the volume, Coping with Terrorism (SUNY Press), edited by Rafael Reuveny and William R. Thompson. Sadly, Gil was still in the process of revising a book manuscript, Liberalism, Realism, and Protracted Nationalist Conflict, before his death.

It must be noted that at the same time that he was been finishing his dissertation, Gil was also engaged in writing a series of reports and monographs for the Jerusalem Media and Communications Centre, where he was a public opinion analyst from 1998 to 2001. He was also a research fellow at the Harry S Truman Research Institute for the Advancement of Peace at Hebrew University from 1998 to 2003 , and a postdoctoral fellow at the Leonard Davis Institute for International Relations at Hebrew University in 2004-05. He joined the department of political science at Tel Aviv as a lecturer in 2005.
Gil wrote the first two lines of the preface to Friedman and Starr's Agency, Structure, and International Politics: "What is it about the way back that makes it seem shorter? Most likely it is the familiarity and the increased understanding that we acquire along the way out" (xii). Gil's mind was all about "the journey"-ever restless, ever asking, ever moving, ever along "the way out." The great tragedy is that Gil's journey was cut so very short, well before he had the opportunity to illuminate the way back.

Gil is survived by his sister Orlie Prince, his brother Ethan Friedman, and his son, Liam Macfarlane. He will be greatly missed by us all.

\section{Harvey Starr University of South Carolina}

\section{BETTY GLAD}

Dr. Betty Glad, 82, died August 2, 2010. She enjoyed a truly distinguished career as a scholar of American politics and foreign policy. Betty was the Olin D. Johnston Professor of Political Science and Distinguished Professor Emerita at the University of South Carolina. She was an exemplary scholar and an expert on the American presidency, U.S. foreign policy, and political leadership. She was the author of Jimmy Carter: In Search of the Great White House; Charles Evans Hughes and the Illusions of Innocence; Key Pittman: The Tragedy of a Senate Insider; and, most recently, An Outsider in the White House: Jimmy Carter, His Advisors, and the Making of American Foreign Policy (Cornell University Press, 2009). Betty was also editor or co-editor of The Psychological Dimensions of War, The Russian Transformation, and other books. In addition, she published dozens of articles, book chapters, and commentary. Her first book, Charles Evans Hughes, was nominated for a Pulitzer Prize.

Betty earned her BS degree magna cum laude and Phi Beta Kappa from the University of Utah. She received her doctorate from the University of Chicago in 1962. Afterwards, she taught at Mt. Holyoke College and Brooklyn College and then taught for many years at the University of IllinoisUrbana-Champaign. She also served as a visiting professor at New York University during the years 1986-88. Betty was one of the first women to earn a Ph.D. in political science and then teach at a Ph.D.-granting institution. She served as the first woman 